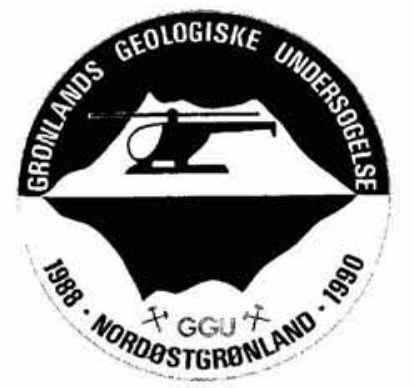

\title{
Stratigraphy and correlation of the Tertiary plateau basalts in North-East Greenland
}

\author{
W. Stuart Watt
}

The Hold with Hope - Wollaston Forland area with the adjacent islands is partly covered by Tertiary plateau basalts. The area is divided into structural blocks by NNE-SSW faults with apparent eastward down-step and the basalt succession of the mainland is repeated on the islands to the east. Individual profiles are correlated using distinctive features of the development of their chemistry with height. A succession of $600-700 \mathrm{~m}$ of uniform tholeitic lavas compose a lower sequence which extends over the whole area. This is overlain locally by an intervolcanic conglomerate followed by $500 \mathrm{~m}$ of variable tholeiites and alkali-basalt lavas. This upper sequence is restricted to the southern part of the volcanic area. The northerly occurrence of a dyke chemically associated with the upper sequence suggests that this sequence originally extended much further north than its present outcrop.

W. S. W., Geological Survey of Greenland, Øster Voldgade 10, DK-1350 Copenhagen $K$, Denmark.

Six hundred kilometres north of the Tertiary plateau basalts in the Scoresby Sund - Kangerlussuaq area of central East Greenland is a second area in which plateau basalts are preserved. This is centred on the Hold with Hope and Wollaston Forland peninsulas (Fig. 1). The total succession of at least $800 \mathrm{~m}$ of subaerial lava flows, apparently broken into fault blocks, is distributed over a number of islands and peninsulas.

One of the objectives of the present study was to provide a stratigraphic framework for the Tertiary lavas in this northern area.

During a three week period in 1989 a total of about $2900 \mathrm{~m}$ of basalt profile were recorded and each flow sampled. For logistic reasons the profiles were concentrated on Wollaston Forland and adjacent islands, as far as possible one in each fault block. A single, long profile on Hold with Hope to the south was considered important as a tie to earlier work in that area by Upton et al. (1980, $1984 a$, b). Orientated samples for a study of the Tertiary magnetic polarity of the lavas were collected throughout most of the profiles.

\section{Earlier work}

Several authors have made passing reference to the basalts of North-East Greenland and studied individual types (see Noe-Nygaard, 1976; Upton et al., 1980, $1984 a, b$ for earlier literature). In the late 1970 s the basalts of Hold with Hope and Giesecke Bjerge in the southern part of this province were investigated (Hald, 1978; Upton et al. 1980, 1984a, b; Thirlwall et al., 1994); these studies include a series of flows from Wollaston Forland (Fig. 1).

\section{Setting and structure}

The areal extent of this northern province of lavas is shown on the 1:250 000 map compiled by Koch \& Haller (1971). Basalt flows are estimated to have covered an elongated area of about $17000 \mathrm{~km}^{2}, 270 \mathrm{~km}$ long and 60 $\mathrm{km}$ wide, extending from Giesecke Bjerge through Hold with Hope, across Wollaston Forland and the islands of Sabine $\varnothing$ and Lille Pendulum to south-east Shannon (Fig. 1). To the east of this line is the Atlantic Ocean and the suggested source of the lavas; to the west isolated outcrops of basalt cap the tops of the higher mountains on Clavering Ø, Palnatoke Bjerg and Kuhn Ø. Some 200 km farther west isolated outcrops of Tertiary alkaline lavas occur in the nunatak zone (Katz, 1952; Brooks et al., 1979); they are thought to represent small-scale flank activity on a melting anomaly and are not further discussed here.

On southern Hold with Hope the basalts are pierced by a shallowly dissected central complex at Myggbukta, and at Kap Broer Ruys the roofed part of a granophyre stock is exposed (Upton et al., 1984b).

The Wollaston Forland - Hold with Hope area where the Tertiary basalts now occur is separated from the Caledonian crystalline rocks to the west by a series of $\mathrm{N}-\mathrm{S}$ faults which drop down the coastal area in relation to the crystalline rocks and Palaeozoic sediments. This major fault system has been active at various times and was 


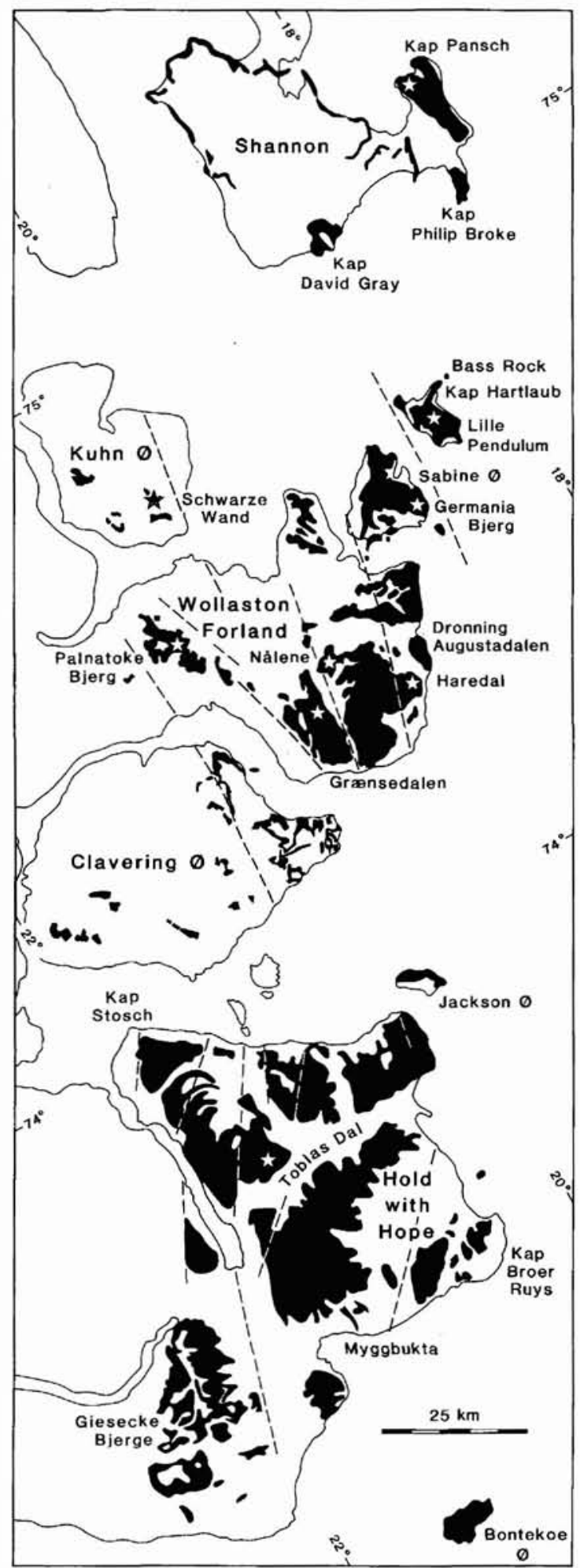

Fig. 1. Sketch map of North-East Greenland showing the extent of the basalts and the major faults of the area. Positions of the profiles discussed in the text are marked by stars. probably reactivated at the onset of volcanism to produce the conglomerate horizons found at the base of the basalts.

The Mesozoic sediments and Tertiary basalts to the east of the major fault system are broken up into blocks by NE-SW faults on Hold with Hope and NNE-SSW faults across Wollaston Forland. Each fault block now has a westerly tilt of about 1 to $4^{\circ}$ independently of each other. Downthrow along these faults appears to be to the east so that the stratigraphically highest parts are now preserved in the low-lying eastern areas. Vertical displacements on these fault lines may be as large as $600 \mathrm{~m}$ (Gransedalen).

Wollaston Forland and Hold with Hope are covered with basalt flows above approximately $500 \mathrm{~m}$ altitude in the west, descending to near sea level in the east. The region was disturbed by faulting along NNE-SSW lines prior to the initiation of volcanic activity, and faulting continued along the same lines after the formation of the lava plateau. In addition to division into fault blocks, the basalts have been affected by widespread landslips.

The preserved lava succession is thickest in the south, with a sequence of about $700-800 \mathrm{~m}$ on Giesecke Bjerge (Upton et al., 1980), and thins eastwards and northwards to about $570 \mathrm{~m}$ on Wollaston Forland and less than $100 \mathrm{~m}$ on Kuhn $\varnothing$ at the northernmost end of the outcrop. On Giesecke Bjerge individual flows can be followed for considerable distances (Upton et al., 1980). Unfortunately observations demonstrating the extent of individual flows are more difficult to make further north.

On the basis of the zeolite content in amygdales discussed by Walker (1974), Upton et al. (1980) estimated that not more than $150 \mathrm{~m}$ had been removed by erosion from the lava flows on Hold with Hope.

In the south where the succession is thickest, it is divided into a lower series of aphyric and plagioclase porphyritic types (Lower Plateau Lava Series of Upton et al., 1980) recognisable over the entire area and an upper series dominated by more olivine-rich and partly alkaline types (Upper Plateau Lava Series) restricted to the southern part of the area.

Although similar to the plateau basalts south of Scoresby Sund the two regions are not necessarily cosanguineous. Age constraints on the volcanic activity in the northern region are poor.

Upton et al. (1980, p. 497) reported a change in the polarity from reversed to normal coinciding with the change from the Lower Plateau Lava Series to the Upper Plateau Lava Series on Giesecke Bjerge. On Hold with Hope they reported that this polarity change appears to occur some way into the Upper Plateau Lava Series.

Orientated samples were collected in 1989 from a profile at Tobias Dal on Hold with Hope up to $30 \mathrm{~m}$ 
above the transition from the Lower to the Upper Series without encountering the polarity change. Thus any polarity change in the Upper Plateau Lava Series on Hold with Hope must come higher in the succession. The whole of the Lower Series appears to fall within a single period of reversed polarity (Nordgerd, 1991). The Upper Series is not present north of Hold with Hope.

The profiles traversed in 1989 were planned to cover the whole of the surviving lava sequence from the underlying Cretaceous sediments or (?Tertiary) conglomerates to the topographically highest features in the area.

Sampling of the profiles was systematic with one sample from the basal part of each flow, ideally $2 \mathrm{~m}$ above the base. In compound flows (a compound flow consisting of several units of seemingly identical composition and appearance) only representative units were sampled.

\section{Pre-basalt sediments}

The basalt lava flows overlie sediments of various ages signifying a period of considerable erosion prior to the onset of volcanism. The youngest sediments directly overlain by lava flows are of Middle Albian age (Lower Cretaceous) but younger sediments (Scaphites Beds of Upper Campanian age from Månedal in northern Traill $\varnothing$, and Knudshoved Beds of ?Upper Santonian - Lower Campanian age on eastern Hold with Hope; Donovan, 1957) are known immediately to the south of the region. At Kap Hartlaub on eastern Lille Pendulum, Vischer (1943, p. 19) reported Tertiary strata containing marine fossils of probable Paleocene-Eocene age, but these were not located on a brief visit there in 1989. Whether they pre- or post-date the volcanic activity is not clear from Vischer's work.

Although basaltic lavas almost invariably overlie yellow Cretaceous sandstones intervening conglomerates were seen in several places and indicate uplift of the region to the west of the present basalt area with rapid erosion of the rejuvenated fault scarp.

On Hold with Hope Upton et al. (1980) reported a conglomerate and arkosic sand unit usually less than 2-3 $\mathrm{m}$ thick underlying the basalt. On Wollaston Forland the base of the Nålene profile lies directly on sandstones of Middle Albian age (H. Nøhr-Hansen, personal communication, 1993), while at Palnatoke Bjerg there are wellrounded gneiss boulders up to $40 \mathrm{~cm}$ in diameter in an underlying conglomerate. At Haredal an underlying conglomerate consists mostly of quartzitic pebbles overlain by a thin tuff. A yellow sandstone containing carbonised and fossil wood and loose quartzitic pebbles underlies the basalt flows on Lille Pendulum and is believed to be Tertiary because of the presence of non-fossilised wood fragments.

\section{Inter-basaltic sediments}

In addition to the pre-basaltic conglomerates there are also sedimentary units between the basalt flows in some areas. At Palnatoke Bjerg a $15 \mathrm{~m}$ thick conglomerate overlying the prominent basal flow is composed entirely of well-rounded basalt boulders. Much of it is zeolitised, with thin intercalations composed of well-rounded fragments of basaltic glass and occasional grains of mafic minerals suggesting a water-lain air-fall tuff. The presence of zeolitised material in the conglomerate indicates that zeolitisation in the basalts pre-dated further uplift or rejuvenation of the fault scarp with subsequent erosion also of parts of the basaltic lavas.

On Shannon there is about $10 \mathrm{~m}$ of unconsolidated yellow quartzitic sandstone between flows; the source of the detritus may have been gneisses similar to those which now crop out on northern Shannon.

In the Tobias Dal section on Hold with Hope a 5-8 m conglomerate composed entirely of basaltic pebbles marks the division between the Lower and Upper Plateau Lava Series.

Red tuffaceous and lateritic horizons between individual flows increase in frequency towards the top of the exposed succession throughout the region.

\section{Plateau basalts}

For convenience the plateau basalts of the region are treated as two main geographical groups separated by 30 $\mathrm{km}$ of water, those on Hold with Hope and those on Wollaston Forland and adjacent islands (Fig. 1). The Wollaston Forland area may be further subdivided into a western (Wollaston Forland) and an eastern (Lille Pendulum, Sabine $\emptyset$ ) group of profiles. The sequence on Shannon is too short to be correlated with other areas.

\section{Hold with Hope (Tobias Dal)}

Tobias Dal lies $50 \mathrm{~km}$ south of the basalt profiles on Wollaston Forland. Although some individual flows may be present in both areas, no attempt was made in the field to correlate in detail the basalt sequences of the two regions.

A profile of about $820 \mathrm{~m}$ of the basalt sequence was sampled below the peak $1285 \mathrm{~m}$ on the northern side of Tobias Dal (Fig. 1). The base of the lava succession is not exposed here, but it is believed to rest directly on the Mesozoic sediments which are widespread on Hold with Hope. No trace of conglomerate underlying the basalt sequence was seen at this point. The lower approximately $600 \mathrm{~m}$, corresponding to the Lower Plateau Lava Series of Upton et al. (1980), is built up of simple and com- 
pound subaerial flows with an average thickness of about $18 \mathrm{~m}$. Most flows of the Lower Plateau Lava Series are grey-brown or red-brown in appearance with a tendency to development of columnar jointing. Petrographically the flows are a mixture of aphyric and porphyritic types with numerous 1 to $3 \mathrm{~mm}$ plagioclase phenocrysts.

The Upper Plateau Lava Series in Tobias Dal is locally separated from the Lower Plateau Lava Series by a basaltic conglomerate. This is the only recorded occurrence of a conglomerate at this stratigraphic position and it coincides with a change in the chemistry. The Upper Plateau Lava Series exceeds $200 \mathrm{~m}$ in thickness and is composed of grey-weathering flows frequently with olivine phenocrysts, some as large as $20 \mathrm{~mm}$, as well as phenocrysts of clinopyroxene and plagioclase.

Hematite, quartz, agate and calcite are common as vesicular minerals in the lower part of the Tobias Dal profile. According to Upton et al. (1980) the calcitequartz assemblage is largely confined to the Tobias Dal region with the Lower Plateau Lava Series in general only showing low temperature zeolite assemblages.

\section{Wollaston Forland (western profiles)}

Profiles were measured in the Wollaston Forland basalts at Grænsedalen $(450 \mathrm{~m})$, Nålene $(615 \mathrm{~m})$ and Haredal $(200 \mathrm{~m})$. Related sequences on Palnatoke Bjerg $(245 \mathrm{~m})$ and Kuhn $\emptyset(115 \mathrm{~m})$ to the north are included in the group of western profiles. The Nålene profile lies $c .8$ $\mathrm{km}$ to the north-east of the Grænsedalen profile, and Haredal c. $13 \mathrm{~km}$ to the south-east of Nålene. The Palnatoke profile is in two parts $4 \mathrm{~km}$ apart about $26 \mathrm{~km}$ north-west of the Grænsedalen profile, while the Kuhn $\emptyset$ profile is $c .45 \mathrm{~km}$ north of Grænsedalen. Each profile lies in a separate fault block, in all of which the basalts dip about 1 to $4^{\circ}$ to the west.

The flows are subaerial, massive, grey to brown weathering, with an average thickness of about $22 \mathrm{~m}$. Compound flows are comparatively common, especially on Nålene where they form up to half the total thickness of the succession. The three topmost flows on Nålene are grey in appearance due to zeolitization of the plagioclase, a feature not seen in their correlatives on Kuhn $\varnothing$ and Sabine $\varnothing$.

The basalt lavas of this group are all fine to medium grained and range from aphyric to plagioclase-phyritic types. In the porphyritic types the plagioclase phenocrysts are usually clusters of laths which together form aggregates 1 to $2 \mathrm{~mm}$ in diameter, but they may also occur as single crystals of similar size. Correlation on the basis of macroscopic phenocrysts, as in the Scoresby Sund region (Larsen et al., 1989), has not been possible, partly due to distance between profiles. No single flow has characteristics which can be used for indisputable field correlation.

Red tuffaceous horizons were more often recorded on the well exposed profile on Nålene than elsewhere within the western group and appear throughout the sequence. The absence of hyaloclastites in this region contrasts with the equivalent successions in Giesecke Bjerge and across Hold with Hope described by Upton et al. (1980) where there are local developments of hyaloclastite with or without pillow lavas.

\section{Lille Pendulum, Sabine $\emptyset$ (eastern profiles)}

The profiles measured in the basalts on Lille Pendulum and Sabine $\varnothing$ lie on a NE-SW line in different fault blocks $10 \mathrm{~km}$ from each other, the nearest about $30 \mathrm{~km}$ east-north-east of Nålene. As the basalts appear to be chemically slightly different from those in the western profiles they are treated separately here.

The succession on Lille Pendulum is approximately $300 \mathrm{~m}$ thick and consists of a series of massive, redbrown weathering flows with an average thickness of about $16 \mathrm{~m}$. The sequence dips at c. $3^{\circ}$ to the south. At the base of the succession fossilised wood and charcoal and quartzitic conglomerate were seen locally. Thin lateritic horizons are present at the top of most flows. Petrographically the flows are fine grained with scattered to numerous $2-3 \mathrm{~mm}$ clusters of plagioclase laths, but clusters may be as large as $8 \mathrm{~mm}$ and include small pyroxene grains.

On Sabine $\emptyset$ exposure is poor and accessible lava flows are confined to the southern part of the island; the northern part dominated by a thick sill extending eastwards across the northern end of Lille Pendulum to Bass Rock. The profile of about $140 \mathrm{~m}$ on the north slope of Germania Bjerg appears to lie within a single fault block tilted c. $12^{\circ}$ to the north-east. The massive, red-brown or brown flows average $11 \mathrm{~m}$ in thickness. A greater number of flows on Sabine $\emptyset$ appear aphyric compared with Lille Pendulum. The porphyritic flows have fairly numerous clusters of plagioclase phenocrysts up to $2-3 \mathrm{~mm}$ in size.

Due to the monotony of the succession a flow to flow correlation between Sabine $\emptyset$ and Lille Pendulum based on field characters could not be established.

\section{Shannon}

Three flows were sampled on a short visit to Kap Pansch. The two lowest flows are aphyric and separated by a black shale with angular basalt fragments. The third flow, separated from the underlying flows by at least $10 \mathrm{~m}$ of unconsolidated, quartzitic sand with iron concretions, contains $3-4 \mathrm{~mm}$ clusters of plagioclase with small py- 
roxene grains between the plagioclase laths. Flow to flow correlation with flows in other areas is not possible.

\section{Sills and dykes}

In the north-eastern part of the plateau basalt area extensive sills form marked topographic features. The massive sill which forms Bass Rock is at least $150 \mathrm{~m}$ thick; it continues across northern Lille Pendulum and covers a large part of northern Sabine $\emptyset$. Sills are particularly prominent on Shannon where they form crescentshaped outcrops encompassing large parts of the island.

Dykes averaging 7-10 $\mathrm{m}$ are scattered throughout the area and cut through the entire exposed basalt sequence. The majority appear to be oriented ESE-WSW with a few close to N-S. A dyke of the ESE-WSW group cuts a sill in Dronning Augustadalen.

\section{Correlation of the profiles on the basis of chemistry}

One of the aims of this work was to obtain as detailed a correlation as possible between profiles in order to detail the structure and movements of the fault blocks and to link together the magnetostratigraphy of the area. As the lava succession is very homogeneous with only minor variation in field characteristics between individual flows, the established correlation is dependent on the pattern of chemical variations eatablished throughout the profiles. This chemical correlation is largely dependent on the fact that there is an elemental cyclicity with height in the sequence which reflects fractionation in the magma chamber. All flows in each profile were sampled, and all samples were analysed for major elements; a selection of samples were also analysed for trace elements.

The sequence pattern of the $\mathrm{TiO}_{2}$ content in relation to height has been used as the basis for flow to flow correlation, with $\mathrm{P}_{2} \mathrm{O}_{5}, m g\left(=\mathrm{MgO} /\left(\mathrm{MgO}+\mathrm{FeO}+\mathrm{Fe}_{2} \mathrm{O}_{3}\right)\right)$ and $\mathrm{Zr} / \mathrm{Nb}$ ratios as support. In the Wollaston Forland area Nålene and Grænsedalen were chosen as standard profiles above and below $800 \mathrm{~m}$ respectively for the western group of profiles, and the Lille Pendulum profile was selected for the eastern group. The stratigraphic heights of individual flows in other profiles were adjusted to give the best possible fit compared to the standard profiles (Figs 3, 5).

Overall a reasonable correlation was established between flows within the geographical groups, viz. Kuhn $\varnothing$, Palnatoke Bjerg, Gransedalen, Nålene and Haredal in the west (Fig. 3), and Sabine $\varnothing$ and Lille Pendulum in the east (Fig. 5; the Nålene profile has been added to Figure 5 for comparative purposes). No attempt was made at a flow to flow correlation with the profile on Hold with Hope.

As a check on the chemically based correlation, the flows were compared for textural characteristics, and the presence of feldspar and pyroxene phenocrysts; however only minor adjustments were made to the correlation.

The whole of the basalt sequence on Wollaston Forland appears to be equivalent to the Lower Plateau Lava Series of Hold with Hope, and will be treated as such in the discussion below. Upton et al. (1984a) drew the same conclusion for a single profile on the south-east flank of Nålene.

\section{Hold with Hope (Tobias Dal)}

While the lavas of the Lower Plateau Lava Series at Tobias Dal are chemically relatively homogeneous from flow to flow, the Upper Plateau Lava Series is marked by a varied chemical composition with tholeitic and alkaline lava types as already documented by Upton et al. $(1980,1984 a, b)$.

\section{Wollaston Forland (western profiles)}

On Wollaston Forland the two longest profiles, viz. Grænsedalen and Nålene, both show a slight general increase in $\mathrm{TiO}_{2}$ with height from just under $2 \%$ at the base of the profiles to close on $2.5 \%$ at the top (Fig. 3).

There appears to be a reasonably good flow to flow chemical correlation between the upper parts of the two long profiles of Grænsedalen and Nålene (Fig. 3).

In the lower part of the two profiles a correlation based only on $\mathrm{TiO}_{2}$ content is less obvious, but the $\mathrm{Zr} / \mathrm{Nb}$ ratio (Fig. 4) suggests a partial overlap, such that the lowest flows of Nalene possibly correspond with the unexposed base of the Grænsedalen succession (Fig. 2). The chemical development from flow to flow on Nålene appears to be steadier with only small changes with stratigraphic height compared to that at Grænsedalen, where $\mathrm{TiO}_{2}$ development from flow to flow is more erratic with occasional extreme jumps. This contrast probably reflects the presence in Grænsedalen of groups of flows absent in the Nålene profile.

Higher in the Grænsedalen profile some other flows occur which appear not to be present on Nålene, although the topmost flow in Grænsedalen does seem to correlate with one on Nålene. In Grænsedalen a single flow stands out by having low $\mathrm{TiO}_{2}$ and $\mathrm{P}_{2} \mathrm{O}_{5}$ contents and a higher $m g$ ratio than any other flow in the region. This implies that certain flows in the upper part of the Grænsedalen profile could have a source independent of those for the lavas in other profiles.

On the basis of $\mathrm{TiO}_{2}$ content the relatively thin flows 


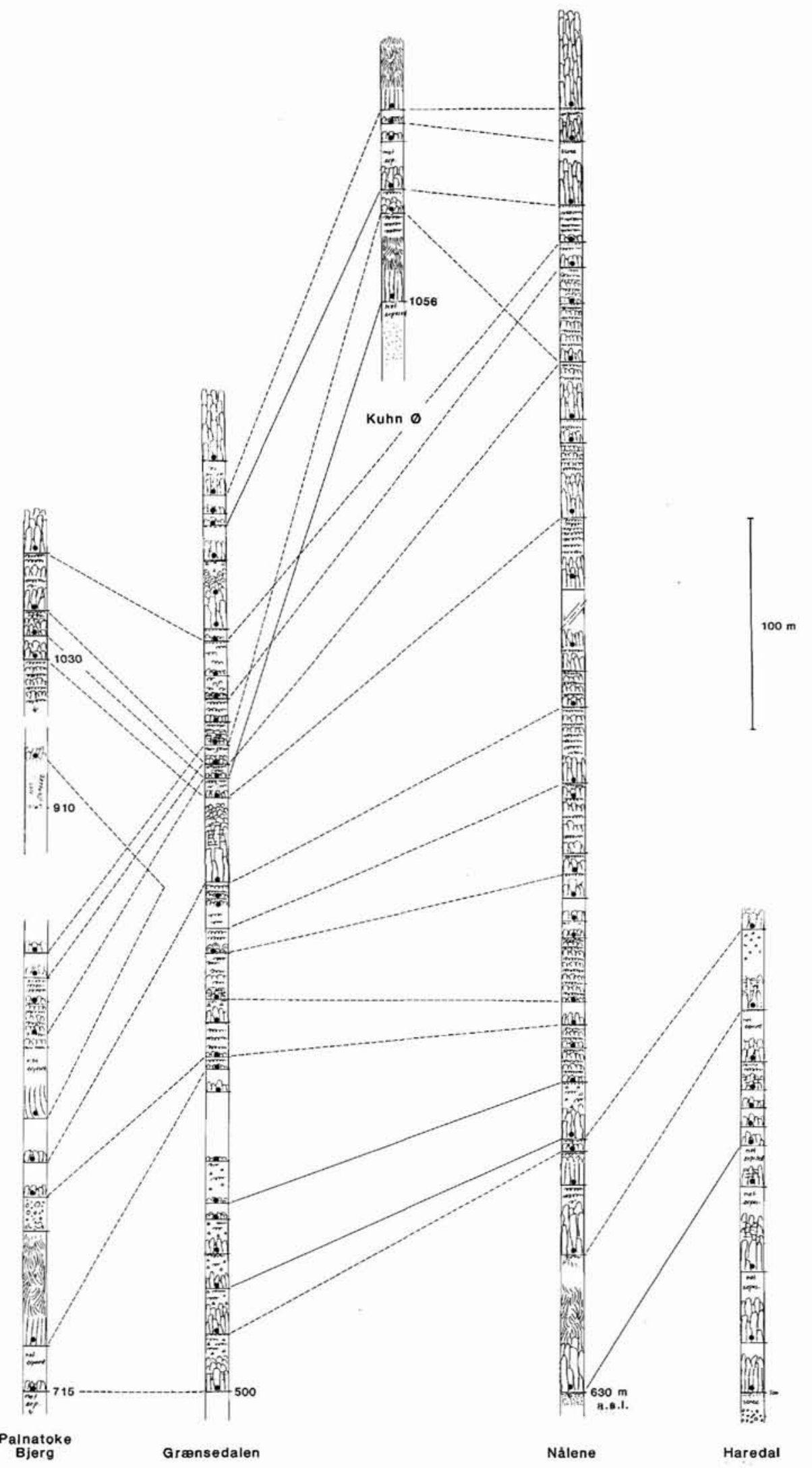

Fig. 2. The western group of profiles on Wollaston Forland with suggested correlation between flows based on the $\mathrm{TiO}_{2}$ content (Fig. 3) and using additional information from stratigraphic height plots of $\mathrm{P}_{2} \mathrm{O}_{5}, m g(=$ $\mathrm{MgO} /(\mathrm{MgO}+\mathrm{FeO}+$ $\left.\mathrm{Fe}_{2} \mathrm{O}_{3}\right)$ ) and $\mathrm{Zr} / \mathrm{Nb}$ ratios. 


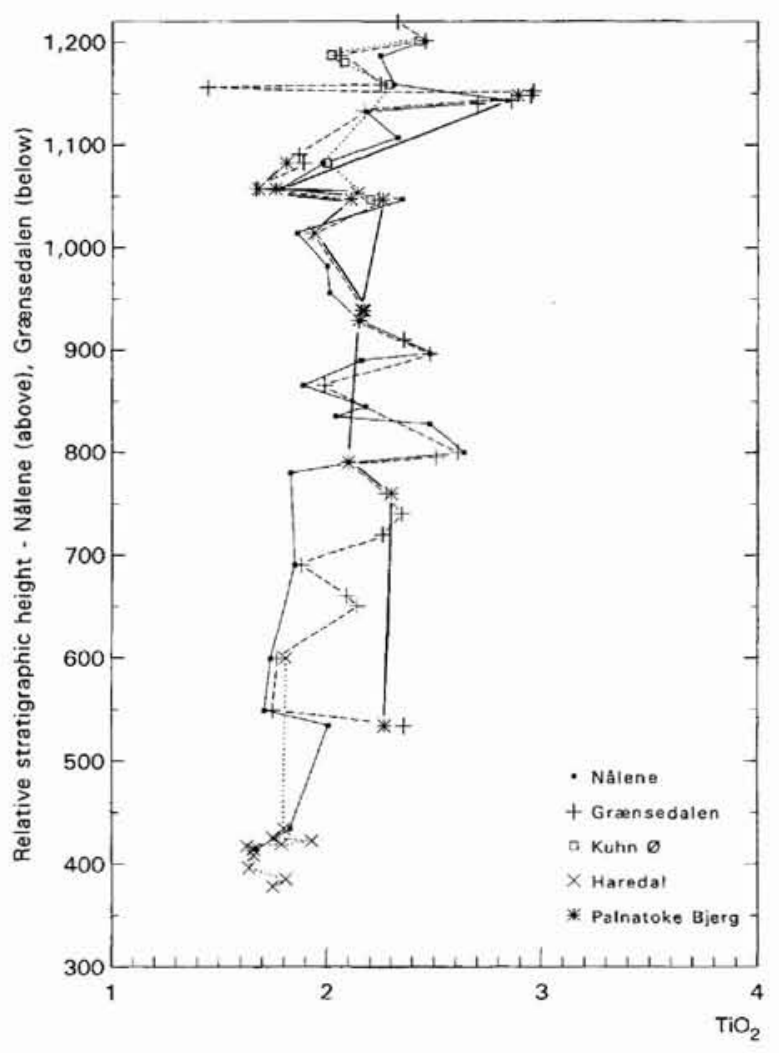

Fig. 3. Plot of $\mathrm{TiO}_{2} v$. stratigraphic height in the western group of profiles on Wollaston Forland. The Grænsedalen (below 800 $\mathrm{m}$ ) and Nålene (above $800 \mathrm{~m}$ ) profiles have been used as standard profiles and the stratigraphic heights of lava flows in the other profiles adjusted to give the best possible fit. This correlation is marked in Figure 2.

characteristic particularly of the Haredal profile appear to correlate well with the base of the Nålene profile. The $\mathrm{Zr} / \mathrm{Nb}$ ratios plotted against stratigraphic height (Fig. 4) show that the lower part of the Haredal profile could extend below Nålene.

The Palnatoke Bjerg profile, about $15 \mathrm{~km}$ north-west of Grænsedalen, is built up of two geographically separated traverses. Due to faulting and landslipping they are partly repetitive. The correlation of the lowest flows is uncertain, but the higher flows all correlate reasonably well with the upper part of the Grænsedalen profile.

On Kuhn $\varnothing$ the flow sequence is comparable to the upper parts of both Nålene and Grænsedalen, but with fewer flows present.

On the basis of the above correlation the total thickness of lava in the western group is estimated as $710 \mathrm{~m}$.

\section{Sabine $\emptyset$ and Lille Pendulum (eastern profiles)}

While in the long profiles further west there is a clear

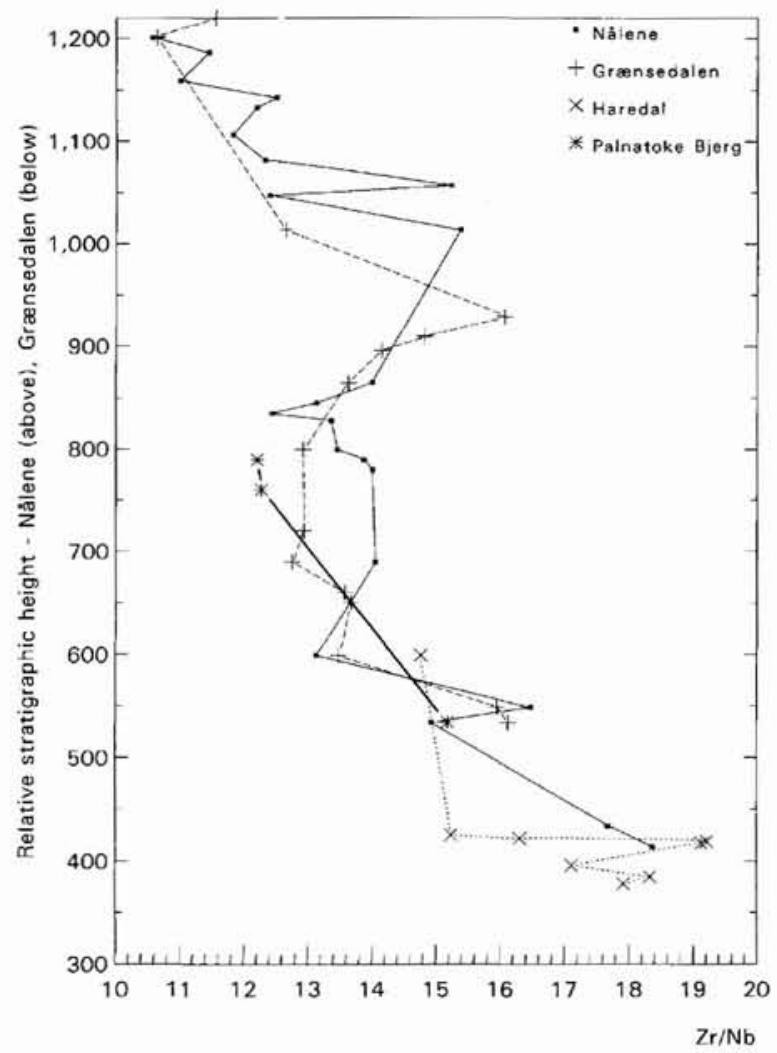

Fig. 4. Plot of $\mathrm{Zr} / \mathrm{Nb}$ ratio $v$. stratigraphic height in the western group of profiles on Wollaston Forland. The same stratigraphic standard profiles and adjustment made as for the $\mathrm{TiO}_{2}$ plot used in Figure 3.

increase in $\mathrm{TiO}_{2}$ content with height, this is not the case on Sabine $\varnothing$ and Lille Pendulum. Hence correlation is entirely dependent on a concordant sequence pattern of the lava chemistry.

In the Lille Pendulum profile two flows stand out by having higher $\mathrm{TiO}_{2}$ (Fig. 5), $\mathrm{P}_{2} \mathrm{O}_{5}$ and lower $m g$ ratios. Only a single flow in the Sabine $\varnothing$ sequence has similar characteristics leading to two possible models for correlation, one where the short Sabine $\emptyset$ profile correlates with the upper part of the Lille Pendulum profile, and the other in which the Sabine $\varnothing$ profile correlates with the lower part of the Lille Pendulum profile. Both models are possible, but if the 'lower' is accepted a number of flows on Sabine $\varnothing$ have no counterpart in the Lille Pendulum profile and would need to be explained by having independent sources for the lavas. If the 'upper' model is accepted all the lower flows on Sabine $\emptyset$ may be correlated with flows in the upper part of the Lille Pendulum sequence, while the uppermost flows of Sabine $\varnothing$ are placed stratigraphically above all the flows on Lille Pen- 


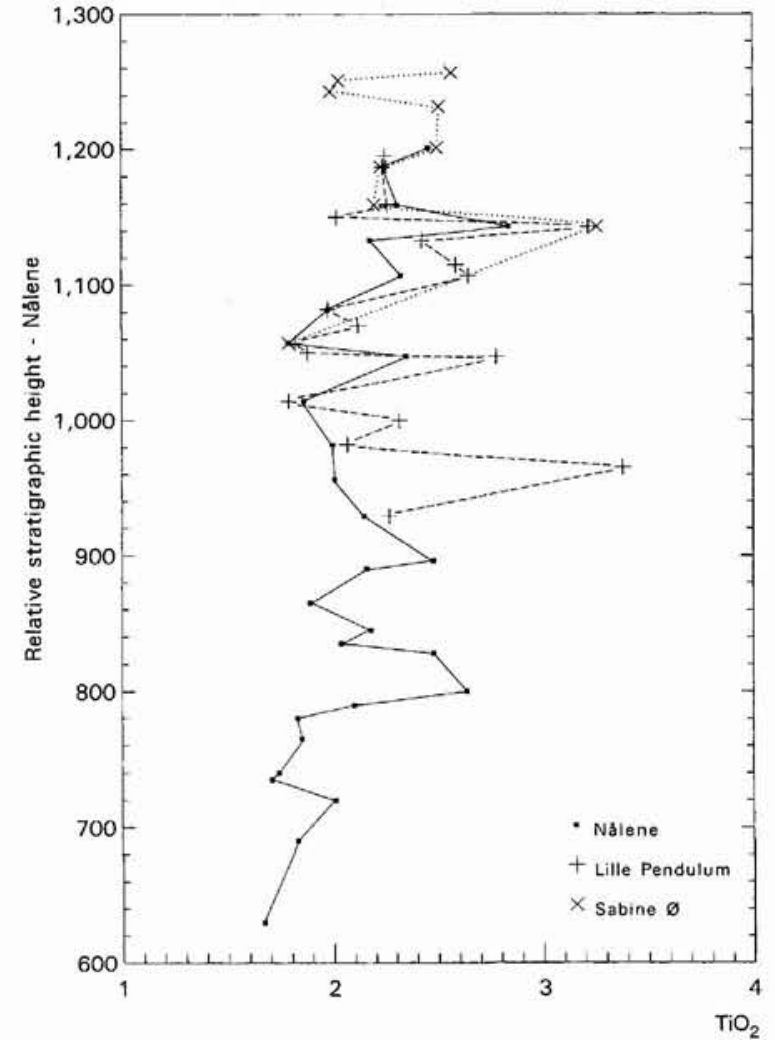

Fig. 5. Plot of $\mathrm{TiO}_{2} v$. stratigraphic height in the eastern group of profiles. The Nålene profile has been used as standard profile and the stratigraphic heights of lava flows in the other two profiles adjusted to give the best possible fit. This correlation is marked in Figure 6.

dulum. The 'upper' correlation model is considered more probable and is used in this account (Figs 5,6).

This interpretation implies that there is a tectonic displacement between the two profiles in the order of $380 \mathrm{~m}$, with an uplift of the eastern block (the Lille Pendulum block) and subsequent erosion of the upper flows from Lille Pendulum. Following the 'upper' model the two profiles give a stratigraphic thickness of $345 \mathrm{~m}$.

The sequence pattern of the three thin flows on Shannon is too short to be correlated with the flows in any other profile, but as their $\mathrm{TiO}_{2}$ content is comparatively high it is suggested that they should be placed high in the stratigraphic sequence. On the other hand the $\mathrm{Zr} / \mathrm{Nb}$ ratio in two of the flows is ambiguous suggesting a placing of one of the flows in the main body of the Wollaston Forland lavas and the one above it considerably higher in the sequence.

\section{Correlation between the western and eastern profiles}

While the western and eastern profiles each form geographical entities there is a distance between the two groups of about $25 \mathrm{~km}$. Considering the difficulties in correlation across the comparatively small distances involved within each group of profiles, the problem is compounded over the greater distance and further com-

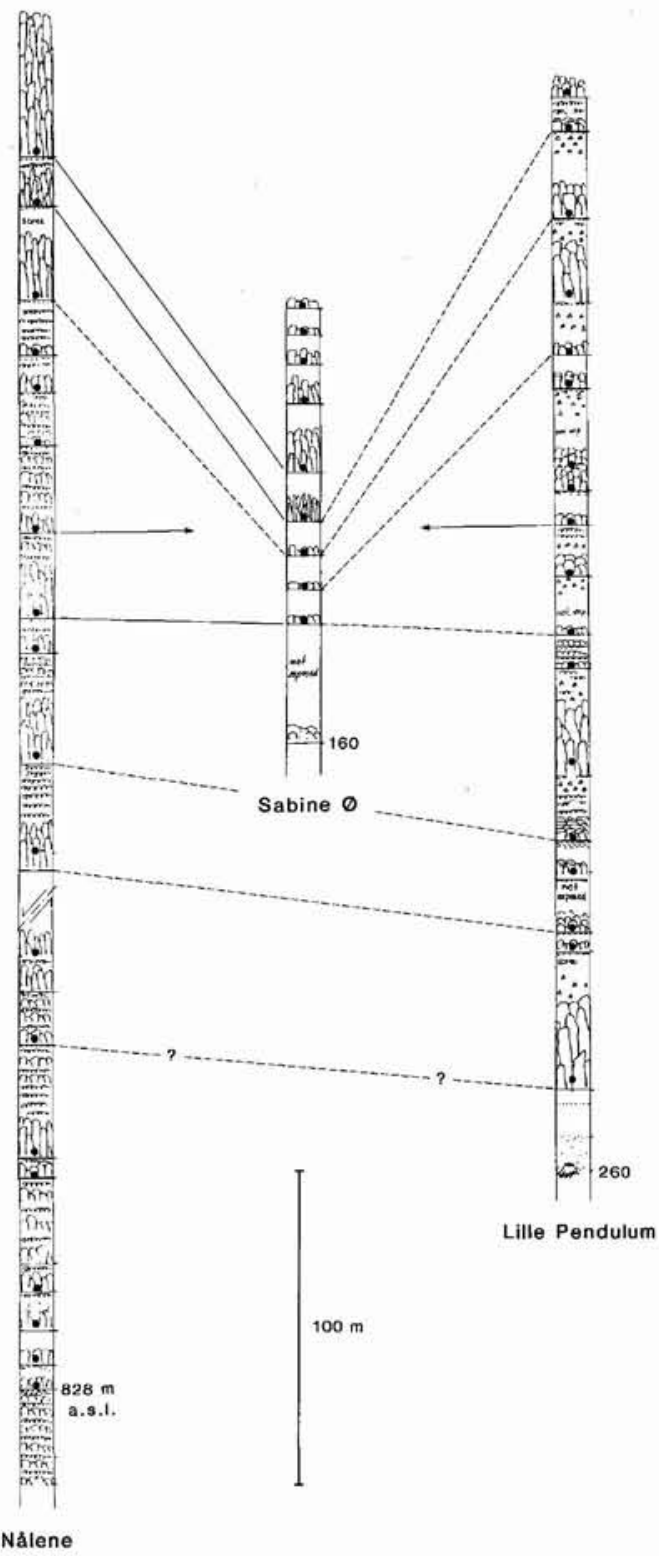

Fig. 6. The eastern group of profiles on Wollaston Forland with suggested correlation between flows based primarily on their $\mathrm{TiO}_{2}$ content (Fig. 5) with support from plots of stratigraphic height $v \cdot \mathrm{P}_{2} \mathrm{O}_{5}, m g$ and $\mathrm{Zr} / \mathrm{Nb}$ ratios. 
plicated by block faulting and the lack of distinctive marker horizons.

As the Nålene profile shows an increase of $\mathrm{TiO}_{2}$ with height, it is most likely that the profiles of Sabine $\emptyset$ Lille Pendulum may be correlated with the upper part of the Nålene sequence (Figs 5,6). Following this correlation the upper basalts of Sabine $\varnothing$ would represent the highest flows in the whole of the Wollaston Forland region. In the lower part of the Lille Pendulum profile the correlation to the Nalene profile is slightly more uncertain, as some flows in each profile appear not to be present in the other.

\section{Summary of the correlation}

The profile measured at Tobias Dal on Hold with Hope is considered too far removed geographically to expect any flow to flow correlation with the Wollaston Forland area, although a general correlation is apparent.

Almost all the profiles on Wollaston Forland and adjacent islands cover approximately the same stratigraphic interval, or parts therof; because of the NNE-SSW block faulting the same succession is repeated in each fault block. The three flows on Shannon, which cannot be correlated with those of Wollaston Forland, can however be placed in the upper part of the succession because of their generally high $\mathrm{TiO}_{2}$ content. The total stratigraphic thickness of the whole region is estimated as $730 \mathrm{~m}$ which is slightly greater than the thickness of $600 \mathrm{~m}$ of the equivalent Lower Plateau Lava Series on Hold with Hope.

Upton et al. (1984a) assumed the source of the basaltic lavas to lie to the east of the surviving outcrops. In general terms, the eastern profiles are the most 'complete', and often thickest, while the sequences further west are more condensed. While a number of flows may be correlated chemically over a large area, there are also many that can only be correlated with flows in adjacent profiles and appear to have had a more restricted areal extent. Occasional flows, such as that at the base of the Palnatoke Bjerg sequence, are only present in the extreme west of the region and appear to have a very restricted geographical distribution; they may fill valley bottoms in a deeply eroded newly uplifted terrain. This suggests that although the main source of the lavas is to the east there must also have been minor local sources.

\section{Sills and dykes}

The dykes normally have $\mathrm{Zr} / \mathrm{Nb}$ ratios similar to the lavas with which they are associated. Two dykes in the Tobias Dal profile have ratios similar to the overlying
Upper Plateau Lava Series, and on Lille Pendulum an ENE-WSW dyke has a very low $\mathrm{Zr} / \mathrm{Nb}$ ratio suggesting that magma similar to the Upper Plateau Lava Series was originally also present in the Lille Pendulum area.

$\mathrm{The} \mathrm{Zr} / \mathrm{Nb}$ ratio of the massive sill of southern Shannon at Kap David Gray and at Bass Rock is high, while the large arc-shaped sill on Shannon, together with the sill cut by a dyke in Dronning Augustadalen show ratios comparable with ratios from the higher parts of the Lower Plateau Lava Series.

\section{General remarks and conclusions}

Compared with the magnitude of the volcanic activity of the Scoresby Sund - Blosseville Kyst region, the flows in Wollaston Forland and Hold with Hope are generally thinner and suggest that the area lay peripheral to the main volcanic activity.

The Upper and Lower Plateau Lava Series, as seen on Hold with Hope, clearly indicate a change in magmatism. An $8 \mathrm{~m}$ conglomerate separating the two units in Tobias Dal may only be a local feature as it has not been recognised elsewhere on Hold with Hope (Hald, 1978; Upton et al., 1980), but it does coincide with the change in magmatism.

The Upper Plateau Lava Series is restricted to Hold with Hope and the adjacent Giesecke Bjerge, although a dyke cutting the lavas in the upper part of the Lower Plateau Lava Series on Lille Pendulum with a very low $\mathrm{Zr} / \mathrm{Nb}$ ratio could indicate that the Upper Plateau Lava Series once had a greater lateral extent.

Lava flows on Shannon, each separated by sedimentary horizons, indicate time gaps in the production at this point. The lowest and highest flows appear to show a 'low' and 'high' placing in the chemical development of the magma, and it is suggested these flows lie on the periphery of the volcanic area.

Upton et al. (1984a) found that their few samples from Wollaston Forland were in general more primitive than those from Hold with Hope. This difference has not been substantiated in the present study, where the Lower Platcau Lava Series in the two areas seems to be more or less identical. However the lower flows on Wollaston Forland are more primitive than the higher flows, a feature already mentioned by Noe-Nygaard \& Pedersen (1974) for the lavas at Kap Stosch on the northern tip of Hold with Hope, while at Tobias Dal there is practically no change with stratigraphic height.

Acknowledgements. The financial support by the Carlsberg Foundation to N. Abrahamsen and P. Nordgerd ensured the logistic basis of the project in Greenland. L. M. Larsen is thanked for constructive criticism of the manuscipt, and M. Watt also for support in the field. 


\section{References}

Brooks, C. K., Pedersen, A. K. \& Rex, D. C. 1979: The petrology and age of alkaline mafic lavas from the nunatak zone of central East Greenland. Bull. Gronlands geol. Unders. 133, $28 \mathrm{pp}$.

Donovan, D. T. 1957: The Jurassic and Cretaceous systems in East Greenland. Meddr Gronland 155(4), 214 pp.

Hald, N. 1978: Tertiary igneous activity at Giesecke Bjerge, northern East Greenland. Bull. geol. Soc. Denmark 27, Spec. Issue. 109-115.

Katz, H. R. 1952: Ein Querschnitt durch die Nunatakzone Ostgrönlands (ca. $74^{\circ}$ n.B.). Meddr Gronland 144(8), 65 pp.

Koch, L. \& Haller, J. 1971: Geological map of East Greenland $72^{\circ} \mathrm{N}-76^{\circ} \mathrm{N}$ lat. (1:250,000). Meddr Gronland 183, 26 pp., 13 map sheets.

Larsen, L. M. , Watt, W. S. \& Watt, M. 1989: Geology and petrology of the Lower Tertiary plateau basalts of the Scoresby Sund region, East Greenland, Bull. Gronlands geol. Unders. 157, $164 \mathrm{pp}$.

Nordgerd, P. A. 1991: Magnetiske undersøgelser af plateaubasalter i nordlige Østgrønland. Speciale ved Lab. Geofysik, Aarhus Universitet. 2 bind.

Noe-Nygaard, A. 1976: Tertiary igneous rocks between Shannon and Scoresby Sund, East Greenland. In Escher, A. \& Watt, W. S. (ed.) Geology of Greenland, 386-402. Copenhagen: Geological Survey of Greenland.
Noe-Nygaard, A. \& Pedersen, A. K. 1974: Progressive chemical variation in a tholeiitic lava sequence at Kap Stosch, northern East Greenland. Bull. geol. Soc. Denmark 23, 175-190.

Thirlwall, M. F., Upton, B. G. J. \& Jenkins, C. 1994: Interaction between continental lithosphere and the Iceland plume $\mathrm{Sr}-\mathrm{Nd}-\mathrm{Pb}$ isotope geochemistry of Tertiary basalts, NE Greenland. J. Petrol. 35, 839-879.

Upton, B. G. J., Emeleus, C. H. \& Hald, N. 1980: Tertiary volcanism in northern E Greenland: Gauss Halvø and Hold with Hope. J. geol. Soc. Lond. 137, 491-508.

Upton, B. G. J., Emeleus, C. H., \& Beckinsale, R. D. 1984a: Petrology of the northern East Greenland Tertiary flood basalts: evidence from Hold with Hope and Wollaston Forland. $J$. Petrol. 25, 151-184.

Upton, B. G. J., Emeleus, C. H., Beckinsale, R. D. \& MacIntyre, R. M. 1984b: Myggbukta and Kap Broer Ruys: the most northerly of the East Greenland Tertiary igneous centres(?). Mineralog. Mag. 48, 323-343.

Vischer, A. 1943: Die postdevonische Tektonik von Ostgrönland zwischen $74^{\circ}$ und $75^{\circ}$ N.Br. Kuhn $\emptyset$, Wollaston Forland, Clavering $\emptyset$ und angrenzende Gebiete. Meddr Gronland 133 (1), 194 pp.

Walker, G. P. L. 1974: The structure of eastern Iceland. In Kristianson, L. (ed.) Geodynamics of Iceland and the North Atlantic area, 177-188. Dordrecht: D. Reidel Publ. Co. 